\title{
STUDI EKSPERIMENTAL KERUNTUHAN RANGKA KUDA-KUDA BAJA RINGAN PADA ATAP RUMAH DAN SEKOLAH
}

\author{
Adityo Budi Utomo ${ }^{1, *)}$, Iman Satyarno ${ }^{2)}$, Muslikh ${ }^{2)}$ \\ ${ }^{1)}$ Prodi Teknologi Konstruksi Jalan dan Jembatan, Politeknik Pekerjaan Umum, Semarang \\ Jl. Prof. H. Soedarto, S.H., Tembalang, Kota Semarang 50275 \\ ${ }^{2)}$ Jurusan Teknik Sipil dan Lingkungan, Universitas Gadjah Mada, Yogyakarta \\ Jl. Grafika No. 2, Kampus UGM, Sinduadi Mlati Sleman Yogyakarta \\ ${ }^{*}$ Email : adityobudiutomo@gmail.com,iman@tsipil.ugm.ac.id
}

\begin{abstract}
Increasingly expensive price of quality woods and difficulties of workmanship, it makes people switch from wood to lightweight steel as a roof truss. The use of lightweight steel as truss becomes popular because of the fast workmanship dan durability of the material. Many cases show that lightweight steel truss at school and house collapsed and caused a fatality. This lightweight steel truss study was carried out on a full scale with a span of $6 \mathrm{~m}$ and a slope of $30^{\circ}$, while the loading test pattern at the placement points of battens was like truss in the community. The goals of this study to measure and observe several parameters including weight, maximum capacity, stiffness, ductility, price, length of work, and failure pattern. From testing, the result shows that lightweight steel truss has dead weight, maximum capacity, stiffness value, ductility value, price, working time, and failure pattern respectively of 21,3 kg,734 kg, 91,18 kg/mm, 2,97, Rp 1.740.000, 2 days, and failure pattern is buckling on the diagonal top chord. The result of this research indicates that lightweight steel truss can be used in the community with the limitation of using metal roof coverings instead of concrete or ceramic and the distance between the truss max 1,2 $\mathrm{m}$.
\end{abstract}

Kata kunci : house, lightweight steel, roof, truss

\section{PENDAHULUAN}

Atap adalah bagian paling atas dari suatu rumah yang berfungsi untuk melindungi rumah dan penghuninya dari pengaruh angin, curah hujan, panas sinar matahari, dan lain-lain. Komponen atap terdiri dari dua bagian penting, yaitu konstruksi kudakuda di bawah penutup atap yang memikul beban penutup atap dan konstruksi penutup atap/pelapis atap yang berfungsi sebagai pelindung kuda-kuda dan elemen bangunan di bawahnya (Yap, 2001).

Masyarakat Indonesia banyak menggunakan material kayu sebagai rangka kuda-kuda atap rumah karena mudah didapat, mudah dibuat, dan ringan. Namun akhir-akhir ini penggunaan bahan kayu untuk rangka kuda-kuda atap rumah menemui beberapa kelemahan antara lain sifat kekuatan kayu yang tidak seragam, mudah diserang rayap bila tidak dirayap dan harga kayu berkualitas yang semakin mahal. Karena kelemahan di atas, masyarakat sudah mulai beralih pada material baja ringan. Namun baja ringan mempunyai beberapa kelemahan antara lain material baja ringan sebagai kuda-kuda memang lebih awet (anti rayap) juga sangat ringan. Namun karena bentuknya yang sangat tipis, baja ringan memiliki kelemahan dalam hal tekuk (Frick, 2002).

Akhir-Akhir ini banyak kasus keruntuhan rangka kuda-kuda baja ringan pada sekolah dan rumah yang baru selesai dikerjakan namun belum diketahui penyebabnya. Untuk menyelidiki penyebab 
kelemahan tekuk pada penggunaan rangka kuda-kuda baja ringan ini perlu dilakukan penelitian secara experimental di laboratorium. Dalam penelitian ini digunakan rangka baja ringan dalam kondisi full scale bentang $6 \mathrm{~m}$ dan sudut $30^{\circ}$ seperti lazimnya digunakan masyarakat. Diharapkan dengan adanya penelitian ini dapat diketahui batasan tekuk pada struktur baja ringan sehingga keruntuhan rangka kuda-kuda dapat dihindari.

\section{Pemodelan Struktur}

Mengacu pada SNI 17.29.1987 (SKBI1.3.53.1987) tentang tata cara perencanaan pembebanan untuk rumah dan gedung, maka beban yang dipikul rangka kuda-kuda antara lain :

a. Beban mati (DL)

Beban mati bekerja vertikal sesuai arah gravitasi (lihat Gambar 1), terdiri dari berat penutup atap (genteng tanah liat atau genteng metal) beserta reng, berat gording, berat langit-langit dan penggantung sebesar $11 \mathrm{~kg} / \mathrm{m}^{2}$, berat sendiri kuda-kuda, danberat abu vulkanik sebesar $2800 \mathrm{~kg} / \mathrm{m}^{3}$

b. Beban hidup (LL)

Beban hidup bekerja vertikal sesuai arah gravitasi (lihat Gambar 1) dilakukan simulasi berbagai kondisi antara lain :

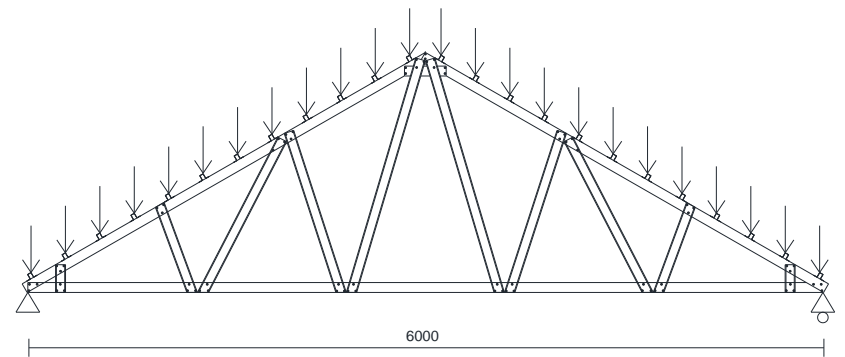

a. Arah kerja beban mati, beban hidup, dan beban hujan
1) beban orang dan pemadam kebakaran beserta peralatannya minimal $100 \mathrm{~kg}$ dan beban horisontal akibat desakan orang sebesar 5\%-10\% dari beban vertikalnya.

2) Beban orang yang bekerja di seluruh atap saat banjir untuk mengungsi

3) Beban orang yang bekerja di sebagian atap saat konstruksi

c. Beban air hujan (R)

Beban air hujan bekerja vertikal sesuai arah gravitasi (lihat gambar 1)

$$
\mathrm{R}=40-0,8 \alpha
$$

dimana :

$\alpha=$ sudut kemiringan atap, derajat (jika $\alpha>50^{\circ}$ dapat diabaikan)

$\mathrm{R}$ = beban air hujan $\mathrm{kg} / \mathrm{m}^{2}\left(\min 20 \mathrm{~kg} / \mathrm{m}^{2}\right)$

d. Beban angin $(\mathrm{W})$

Angin yang menerpa atap akan memunculkan beban angin berupa tekanan dan hisapan. Beban angin bekerja tegak lurus terhadap bidang kemiringan atap dan besarnya minimum $25 \mathrm{~kg} / \mathrm{m}^{2}$ (jauh dari laut) dan minimum $40 \mathrm{~kg} / \mathrm{m}^{2}(5 \mathrm{~km}$ dari laut) atau diambil rumus pendekatan

$$
\mathrm{P}=\frac{V^{2}}{16}\left(\mathrm{~kg} / \mathrm{m}^{2}\right)
$$

dimana :

Koefisien angin tekan $\left(\mathrm{W}_{\text {tekan }}\right)=0,02 \alpha-0,4$

Koefisien angin hisap $\left(\mathrm{W}_{\text {hisap }}\right)=0,4$

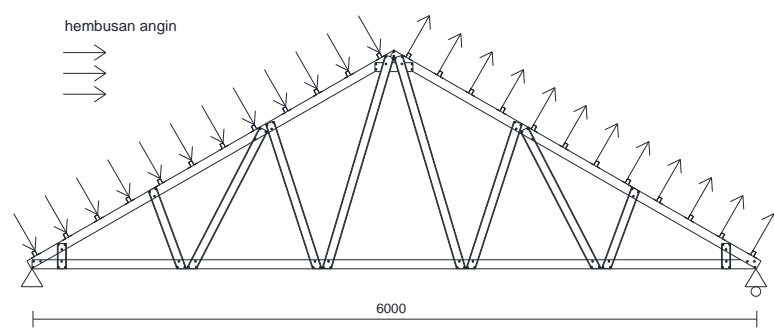

b. Arah kerja beban angin

Gambar 1. Arah kerja beban yang bekerja pada rangka kuda-kuda 
Tabel 1. Kombinasi beban layan rangka atap baja ringan dengan genteng metal dan genteng tanah liat pada jarak antar kuda-kuda 1,2 $\mathrm{m}$

\begin{tabular}{|c|c|c|c|c|c|c|c|c|c|c|c|c|}
\hline \multirow[b]{2}{*}{ Beban Layan } & \multicolumn{4}{|c|}{ Beban Atap } & \multicolumn{2}{|c|}{ Beban Hidup } & \multirow{2}{*}{$\begin{array}{c}\text { Beban } \\
\text { angin } \\
\text { arah } \\
\text { vertikal } \\
(\mathrm{Wy}) \\
(\mathrm{kg})\end{array}$} & \multirow[b]{2}{*}{$\begin{array}{c}\text { Beban air } \\
\text { hujan } \\
(\mathrm{kg})\end{array}$} & \multirow[b]{2}{*}{$\begin{array}{c}\text { Beban } \\
\text { pasir abu } \\
\text { vulkanik } \\
3 \mathrm{~cm} \\
(\mathrm{~kg})\end{array}$} & \multirow{3}{*}{ Keterangan } & \multirow{3}{*}{$\begin{array}{l}\text { Total } \\
\text { beban } \\
\text { silinder } \\
\text { beton } \\
\text { (buah) }\end{array}$} & \multirow[b]{2}{*}{$\begin{array}{r}\text { Berat } \\
\text { total } \\
(\mathrm{kg})\end{array}$} \\
\hline & $\begin{array}{c}\text { Beban } \\
\text { reng } \\
(\mathrm{kg}) \\
\end{array}$ & $\begin{array}{c}\text { Beban } \\
\text { genteng } \\
\text { tanah liat } \\
(\mathrm{kg})\end{array}$ & $\begin{array}{c}\text { Beban } \\
\text { genteng } \\
\text { metal }\end{array}$ & $\begin{array}{c}\begin{array}{c}\text { Beban } \\
\text { plafon }\end{array} \\
(\mathrm{kg}) \\
\end{array}$ & $\begin{array}{c}\text { Beban } \\
\text { orang } \\
\text { sebagian } \\
(\mathrm{kg})\end{array}$ & $\begin{array}{c}\text { Beban } \\
\text { orang } \\
\text { penuh } \\
(\mathrm{kg}) \\
\end{array}$ & & & & & & \\
\hline $\begin{array}{l}\text { Konversi jumlah } \\
\text { silinder beton } \\
\text { (buah) }\end{array}$ & $\begin{array}{l}2 \\
\left(\begin{array}{l}@ \\
\mathrm{~kg})\end{array}\right.\end{array}$ & $\begin{array}{l}20 \\
(@ 12 \\
\mathrm{kg})\end{array}$ & $\begin{array}{l}3 \\
\left(\begin{array}{l}@ \\
\mathrm{~kg})\end{array}\right.\end{array}$ & $\begin{array}{l}7 \\
(\text { @ } 12 \\
\mathrm{kg})\end{array}$ & $\begin{array}{l}32 \\
(\text { @ } 12 \\
\mathrm{kg})\end{array}$ & $\begin{array}{l}58 \\
(@ 12 \\
\mathrm{kg})\end{array}$ & $\begin{array}{l}4 \\
(@ 12 \\
\mathrm{kg})\end{array}$ & $\begin{array}{l}12 \\
(\text { @ } 12 \\
\mathrm{kg})\end{array}$ & $\begin{array}{l}49 \\
(@ 12 \\
\mathrm{kg})\end{array}$ & & & \\
\hline Komb 1a & $\mathrm{x}$ & & $\mathrm{x}$ & $\mathrm{x}$ & & & & & & $\begin{array}{l}\text { rangka kuda-kuda selesai } \\
\text { dikerjakan dengan atap } \\
\text { metal }\end{array}$ & 12 & 141 \\
\hline Komb 3a & $\mathrm{x}$ & & $\mathrm{x}$ & $\mathrm{x}$ & & & $\mathrm{x}$ & $\mathrm{x}$ & & kejadian hujan + angin & 27 & 327 \\
\hline Komb 5a & $\mathrm{x}$ & & $\mathrm{x}$ & $\mathrm{x}$ & $\mathrm{x}$ & & & & & pemadam kebakaran & 43 & 520 \\
\hline Komb 6a & $\mathrm{x}$ & & $\mathrm{x}$ & $\mathrm{x}$ & & & & & $\mathrm{x}$ & $\begin{array}{l}\text { Kejadian hujan abu } \\
\text { vulkanik tebal } 3 \mathrm{~cm}\end{array}$ & 61 & 729 \\
\hline Komb 7a & $\mathrm{x}$ & & $\mathrm{x}$ & $\mathrm{x}$ & & $\mathrm{x}$ & & & & evakuasi bencana & 70 & 841 \\
\hline Komb $1 b$ & $\mathrm{x}$ & $\mathrm{x}$ & & $\mathrm{x}$ & & & & & & $\begin{array}{l}\text { rangka kuda-kuda selesai } \\
\text { dikerjakan dengan genteng } \\
\text { tanah liat }\end{array}$ & 29 & 351 \\
\hline Komb 2b & $\mathrm{x}$ & & & & $\mathrm{x}$ & & & & & $\begin{array}{l}\text { proses pemasangan rangka } \\
\text { kuda-kuda }\end{array}$ & 33 & 399 \\
\hline Komb $3 b$ & $\mathrm{x}$ & $\mathrm{x}$ & & $\mathrm{x}$ & & & $\mathrm{x}$ & $\mathrm{x}$ & & kejadian hujan + angin & 45 & 537 \\
\hline
\end{tabular}




\begin{tabular}{|c|c|c|c|c|c|c|c|c|c|c|c|c|}
\hline \multirow[b]{2}{*}{ Beban Layan } & \multicolumn{4}{|c|}{ Beban Atap } & \multicolumn{2}{|c|}{ Beban Hidup } & \multirow[b]{2}{*}{$\begin{array}{c}\text { Beban } \\
\text { angin } \\
\text { arah } \\
\text { vertikal } \\
(\mathrm{Wy}) \\
(\mathrm{kg})\end{array}$} & \multirow[b]{2}{*}{$\begin{array}{c}\text { Beban air } \\
\text { hujan } \\
(\mathrm{kg})\end{array}$} & \multirow[b]{2}{*}{$\begin{array}{c}\text { Beban } \\
\text { pasir abu } \\
\text { vulkanik } \\
3 \mathrm{~cm} \\
(\mathrm{~kg})\end{array}$} & \multirow{3}{*}{\multicolumn{2}{|c|}{ Keterangan }} & \multirow[b]{2}{*}{$\begin{array}{r}\text { Berat } \\
\text { total } \\
(\mathrm{kg})\end{array}$} \\
\hline & $\begin{array}{c}\text { Beban } \\
\text { reng } \\
(\mathrm{kg})\end{array}$ & $\begin{array}{c}\text { Beban } \\
\text { genteng } \\
\text { tanah liat } \\
(\mathrm{kg})\end{array}$ & 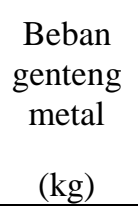 & $\begin{array}{c}\text { Beban } \\
\text { plafon } \\
(\mathrm{kg})\end{array}$ & $\begin{array}{c}\begin{array}{c}\text { Beban } \\
\text { orang } \\
\text { sebagian }\end{array} \\
(\mathrm{kg})\end{array}$ & $\begin{array}{c}\text { Beban } \\
\text { orang } \\
\text { penuh }\end{array}$ & & & & & & \\
\hline $\begin{array}{l}\text { Konversi jumlah } \\
\text { silinder beton } \\
\text { (buah) }\end{array}$ & $\begin{array}{c}2 \\
(@ 12 \\
\mathrm{kg})\end{array}$ & $\begin{array}{l}20 \\
(\text { @ } 12 \\
\mathrm{kg})\end{array}$ & $\begin{array}{l}3 \\
\left(\begin{array}{l}@ \\
\mathrm{~kg})\end{array}\right.\end{array}$ & $\begin{array}{c}7 \\
(\text { @ } 12 \\
\mathrm{kg})\end{array}$ & $\begin{array}{l}32 \\
(\text { @ } 12 \\
\mathrm{kg})\end{array}$ & $\begin{array}{l}58 \\
(\text { @ } 12 \\
\mathrm{kg})\end{array}$ & $\begin{array}{c}4 \\
(\text { @ } 12 \\
\mathrm{kg})\end{array}$ & $\begin{array}{l}12 \\
(@ 12 \\
\mathrm{kg})\end{array}$ & $\begin{array}{l}49 \\
(@ 12 \\
\mathrm{kg})\end{array}$ & & & \\
\hline Komb 4b & $\mathrm{x}$ & & & & & $\mathrm{x}$ & & & & $\begin{array}{l}\text { pemasangan atap secara } \\
\text { gotong royong }\end{array}$ & 60 & 720 \\
\hline Komb 5b & $\mathrm{x}$ & $\mathrm{x}$ & & $\mathrm{x}$ & $\mathrm{x}$ & & & & & pemadam kebakaran & 61 & 730 \\
\hline Komb 6b & $\mathrm{x}$ & $\mathrm{x}$ & & $\mathrm{x}$ & & & & & $\mathrm{x}$ & $\begin{array}{l}\text { Kejadian hujan abu } \\
\text { vulkanik tebal } 3 \mathrm{~cm}\end{array}$ & 78 & 939 \\
\hline Komb $7 b$ & $\mathrm{x}$ & $\mathrm{x}$ & & $\mathrm{x}$ & & $\mathrm{x}$ & & & & $\begin{array}{l}\text { proses evakuasi bencana } \\
\text { yang dimana orang } \\
\text { menaiki atap rumah }\end{array}$ & 88 & 1051 \\
\hline
\end{tabular}

Sumber : Utomo, 2016 
Rangka kuda-kuda baja ringan dimodelkan dengan bentang $6 \mathrm{~m}$, sudut $30^{\circ}$, jarak antar kuda-kuda 1,2 $\mathrm{m}$ dan jarak antar reng 0,22 $\mathrm{cm}$. Beban yang bekerja pada rangka kudakuda terjadi dalam berbagai kombinasi sehingga disebut beban layan (service load). Beban layan yang mungkin terjadi dapat dilihat dalam Tabel 1. Dalam table juga dimungkingkan kondisi darurat seperti kondisi bencana banjir (dimana dipergunakan untuk mengungsi) dan kondisi bencana letusan gunung berapi (dimana penutup atap tertutup tebal oleh abu vulkanik). (Basukito, 2010) Penyaluran beban mulai dari penutup atap hingga kolom disalurkan melalui rangka batang kuda-kuda dan hasil pemodelan dapat digambarkan dalam Gambar 2. Penyaluran beban dari penutup atap melalui rangka batang kuda-kuda menyebabkan terjadinya respon struktur berupa gaya batang dan lendutan. Menurut SNI 03-2847-2002 butir 6.4.3 Lendutan ijin $(\delta)$ yang terjadi sebaiknya lebih kecil dari $\frac{1}{480} \times \mathrm{L}$ (panjang bentang kuda-kuda). Lendutan yang melebihi lendutan ijin akan mengakibatkan kerusakan non struktural seperti retak plafon dan turunnya posisi instalasi listrik.

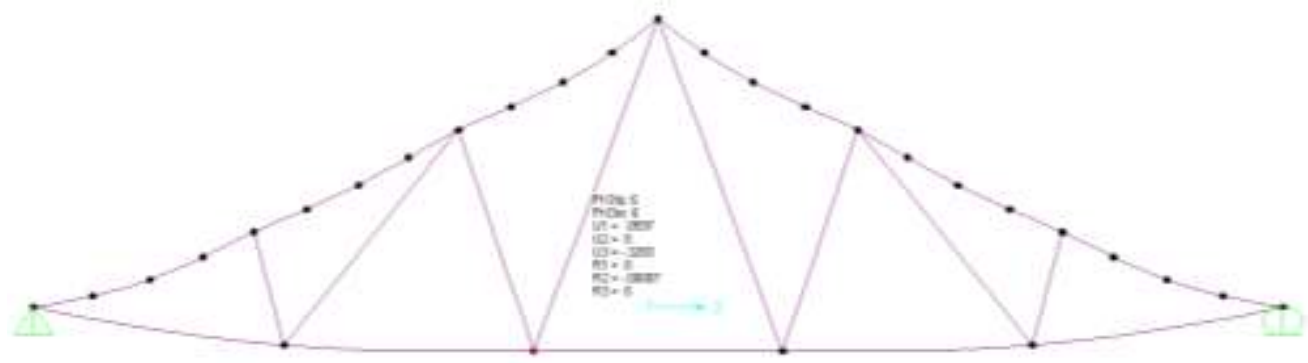

Gambar 2. Reaksi batang akibat beban pada struktur rangka baja ringan dengan SAP

\section{METODE PENELITIAN}

Metode penelitian ini diawali dengan studi pustaka terhadap literatur yang sesuai, ,elakukan pemodelan strukstur dengan bantuan software SAP 2000, pembuatan gambar kerja, dan pembuatan model kudakuda yang akan diuji. Penelitian ini menggunakan rangka kuda-kuda baja ringan yang ada di masyarakat dengan bentang $6 \mathrm{~m}$ dan sudut kemiringan penutup atap sebesar $30^{\circ}$. Rangka utama kuda-kuda baja ringan menggunakan profil C75.35. Adapun bentuk rangka kuda-kuda dapat dilihat dalam Gambar 3.

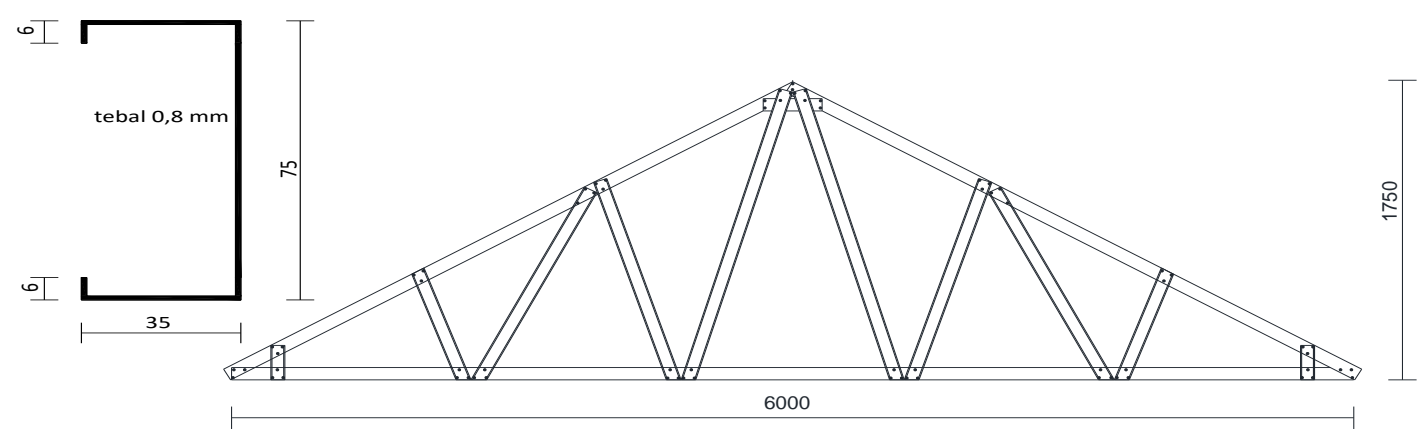

Gambar 3. Model alternatif struktur rangka kuda-kuda atap rumah 
Untuk memodelkan arah kerja beban yang bekerja pada rangka kuda-kuda, dalam penelitian ini digunakan simulasi dengan silinder beton yang diletakkan dalam keranjang seperti terlihat dalam Gambar 4 di bawah. Pemodelan pengujian kuda-kuda dengan beban vertikal hanya dapat mensimulasi arah kerja beban mati, beban hidup, dan beban hujan, sedangkan beban angin yang bekerja secara horisontal tidak bisa disimulasi dalam pengujian ini.

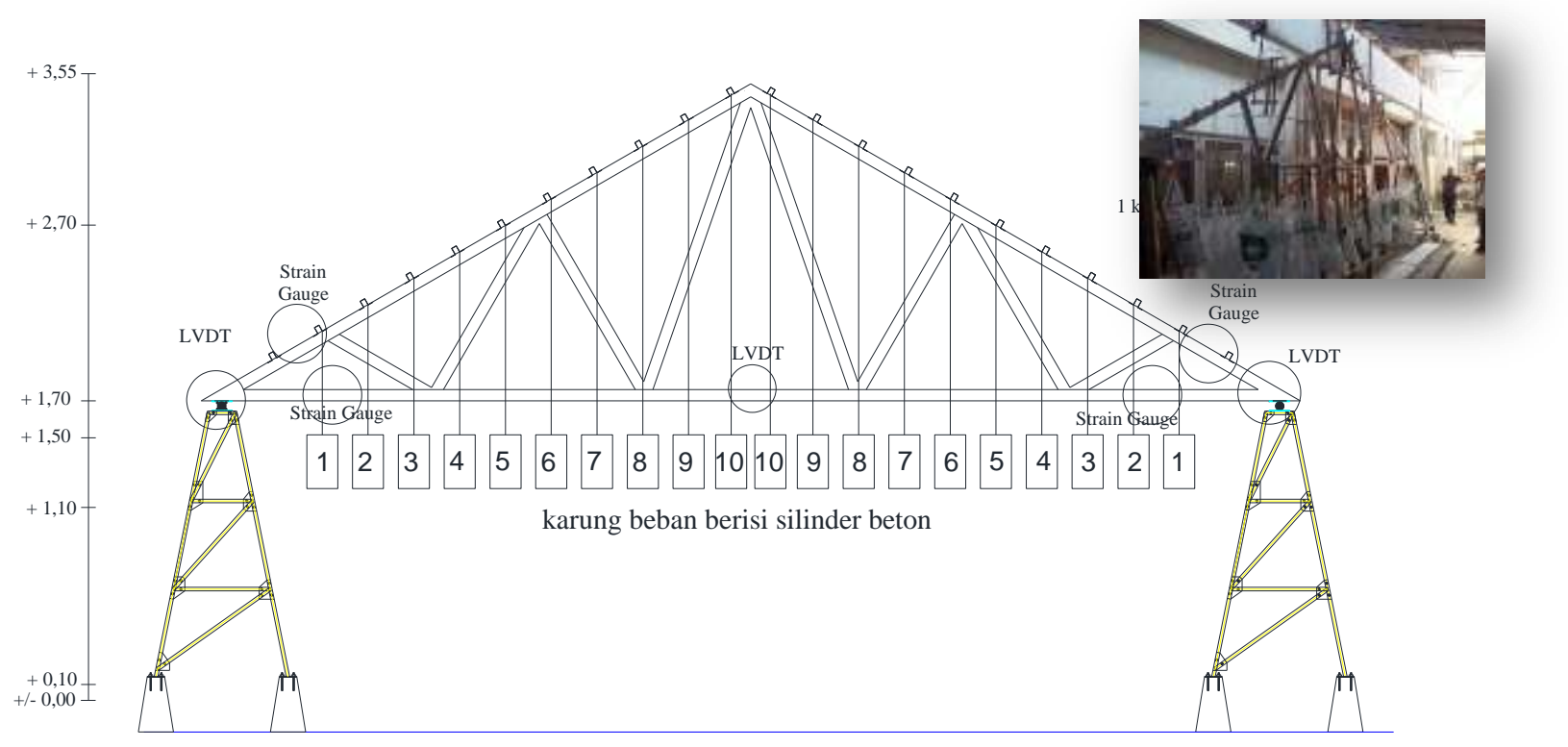

Gambar 4. Metode pengujian struktur rangka baja ringan dengan menggunakan karung beban

\section{HASIL DAN PEMBAHASAN}

\section{a. Berat Struktur Rangka Kuda-Kuda}

Pengukuran berat rangka baja ringan dilakukan dengan cara meletakkan sampel rangka ringan sepanjang 6 meter dan sudut $30^{\circ}$ pada sebuah

\section{b. Perilaku Beban Dan Lendutan Struktur Rangka Kuda-Kuda}

Setiap penambahan silinder akan menimbulkan penambahan lendutan timbangan. Berat 1 set rangka kudakuda baja ringan adalah 21,3 kg yang artinya dapat diangkat oleh 1 orang. Dalam pelaksanaannya karena memiliki bentang yang cukup panjang maka dilakukan oleh 2 orang.

pada tengah bentang kuda-kuda. Kurva beban terhadap lendutan kuda-kuda dapat dilihat dalam Gambar 5. 


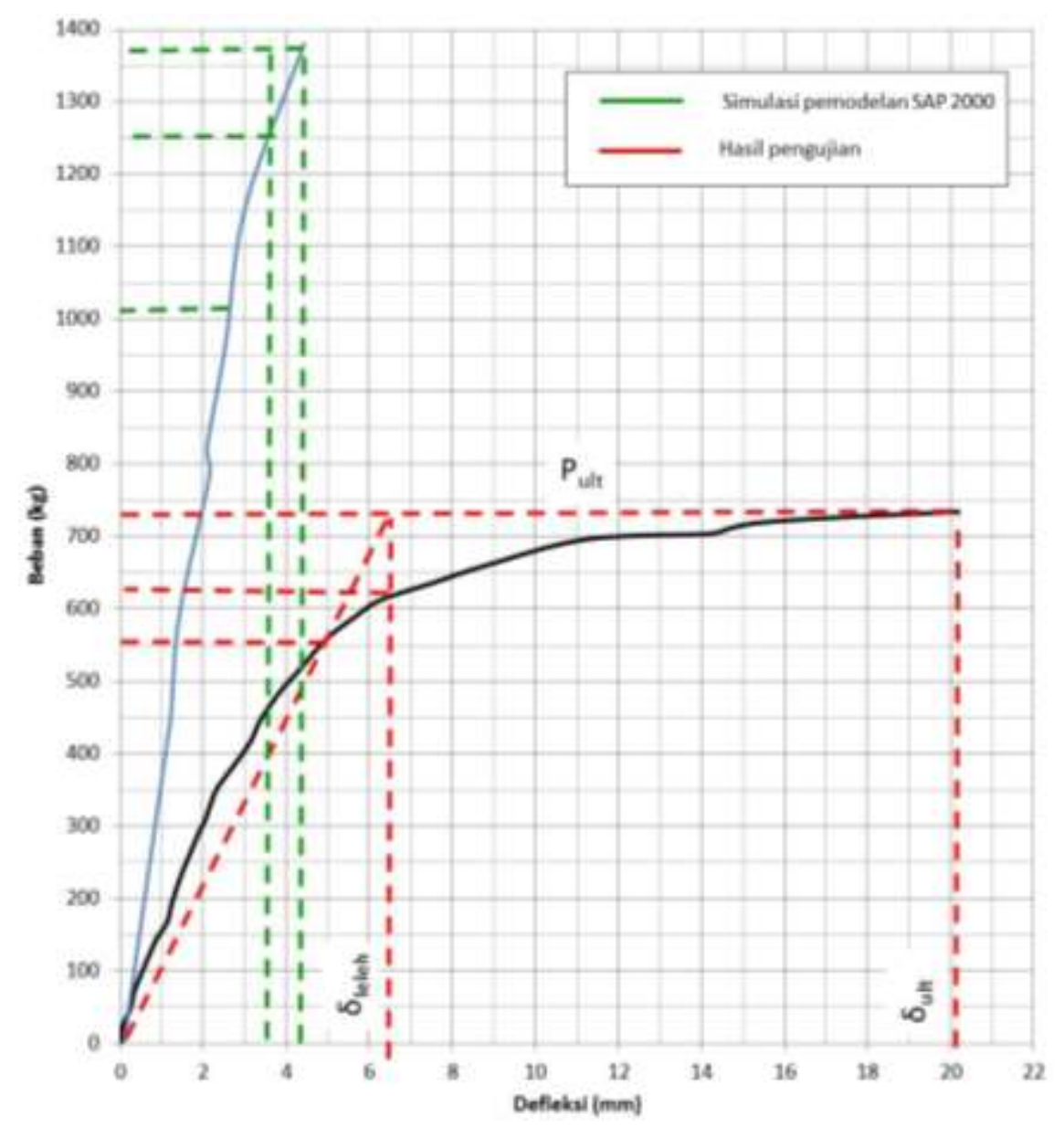

Gambar 5. Kurva hubungan beban dan lendutan rangka kuda-kuda baja ringan (sumber : Utomo, 2016)

Secara umum dapat dilihat perilaku struktur rangka baja ringan bersifat linier elastis kemudian berubah menjadi non linier dan inelastik. Kekakuan struktur berkaitan dengan kemampuan struktur menahan respon elastik sebelum leleh terjadi. Daktilitas struktur berkaitan dengan kemampuan struktur untuk menahan respon inelastik (telah terjadi leleh) termasuk menyerap energi dan lendutan. Kuda-kuda baja ringan dalam penelitian ini dinilai memiliki daktilitas yang tinggi (Tabel 2) sehingga struktur tersebut mampu mengalami simpangan paling besar sebelum runtuh bila terjadi beban dinamik (seperti beban gempa).

Tabel 2. Analisa kekakuan dan daktilitas rangka kuda-kuda baja ringan

\begin{tabular}{lcccccc}
\hline & \multicolumn{2}{c}{ Kondisi Ultimate } & \multicolumn{2}{c}{ Kondisi Leleh } & Nilai Kekakuan & $\begin{array}{c}\text { Nilai } \\
\text { Daktilitas }\end{array}$ \\
\cline { 2 - 7 } & $\begin{array}{c}\mathrm{P}_{\mathrm{ult}} \\
\left(\mathrm{P}_{\mathrm{u}}\right)\end{array}$ & $\delta_{\mathrm{ult}}\left(\delta_{\mathrm{u}}\right)$ & $\mathrm{P}_{\text {leleh }}\left(\mathrm{P}_{\mathrm{y}}\right)$ & $\begin{array}{c}\delta_{\text {leleh }} \\
\left(\delta_{\text {leleh }}\right)\end{array}$ & $\mathrm{P}_{\mathrm{y}} / \delta_{\mathrm{y}}$ & $\delta_{\mathrm{y}} / \delta_{\mathrm{u}}$ \\
\hline Hasil simulasi & $1350 \mathrm{~kg}$ & $4,3 \mathrm{~mm}$ & $1250 \mathrm{Kg}$ & $3,5 \mathrm{~mm}$ & $347,22 \mathrm{Kg} / \mathrm{mm}$ & 1,23 \\
\hline Hasil pengujian & $734 \mathrm{Kg}$ & $6,8 \mathrm{~mm}$ & $620 \mathrm{Kg}$ & $20,2 \mathrm{~mm}$ & $91,18 \mathrm{Kg} / \mathrm{mm}$ & 2,97 \\
\hline
\end{tabular}


Hasil pengujian (Gambar 6) akan dibandingkan dengan besar beban kombinasi (Tabel 1 dan 2) sehingga diperoleh faktor keamanan $(\mathrm{SF}=$ Safety Factor) untuk alasan keamanan bila nantinya kuda-kuda diterapkan di masyarakat. Kekuatan kuda-kuda terhadap kombinasi beban setidaknya memiliki $\mathrm{SF}>1$, berikut analisis faktor keamanan rangka kuda-kuda hasil pengujian dapat dilihat dalam Tabel 3.

Tabel 3. Analisis faktor keamanan struktur rangka kuda-kuda hasil pengujian

\begin{tabular}{rcc}
\hline \multirow{2}{*}{$\begin{array}{c}\text { Kombinasi } \\
\text { beban } \\
\text { (jarak 1,2 m) }\end{array}$} & $\begin{array}{c}\text { Faktor keamanan (SF) } \\
\text { struktur rangka baja ringan }\end{array}$ \\
\cline { 2 - 3 } & $\begin{array}{c}\text { Kondisi } \\
(734 \mathrm{Kg})\end{array}$ & $\begin{array}{c}\text { Kondisi } \\
\text { leleh } \\
(620 \mathrm{Kg})\end{array}$ \\
\hline $\begin{array}{r}\text { Kombinasi 1a } \\
(141 \mathrm{Kg})\end{array}$ & 5,21 & 4,40 \\
\hline $\begin{array}{r}\text { Kombinasi 2a } \\
(327 \mathrm{Kg})\end{array}$ & 2,24 & 1,90 \\
\hline $\begin{array}{r}\text { Kombinasi 3a } \\
(520 \mathrm{Kg})\end{array}$ & 1,41 & 1,19 \\
\hline $\begin{array}{r}\text { Kombinasi 4a } \\
(729 \mathrm{Kg})\end{array}$ & 1,01 & 0,85 \\
\hline $\begin{array}{r}\text { Kombinasi 5a } \\
(841 \mathrm{Kg})\end{array}$ & 0,87 & 0,74 \\
\hline
\end{tabular}

Faktor keamanan (SF)

\begin{tabular}{|ccc}
$\begin{array}{c}\text { Kombinasi } \\
\text { beban } \\
\text { (jarak } 1,2 \mathrm{~m})\end{array}$ & $\begin{array}{c}\text { Kondisi } \\
\text { ultimate } \\
(734 \mathrm{Kg})\end{array}$ & $\begin{array}{c}\text { Kondisi } \\
\text { leleh } \\
(620 \mathrm{Kg})\end{array}$ \\
\hline $\begin{array}{r}\text { Kombinasi } 1 \mathrm{~b} \\
(351 \mathrm{Kg})\end{array}$ & 2,09 & 1,77 \\
\hline $\begin{array}{r}\text { Kombinasi } 2 \mathrm{~b} \\
(399 \mathrm{Kg})\end{array}$ & 1,84 & 1,55 \\
\hline $\begin{array}{r}\text { Kombinasi 3b } \\
(537 \mathrm{Kg})\end{array}$ & 1,37 & 1,15 \\
\hline $\begin{array}{r}\text { Kombinasi 4b } \\
(720 \mathrm{Kg})\end{array}$ & 1,02 & 0,86 \\
\hline $\begin{array}{r}\text { Kombinasi } 5 \mathrm{~b} \\
(730 \mathrm{Kg})\end{array}$ & 1,01 & 0,85 \\
\hline $\begin{array}{r}\text { Kombinasi 6b } \\
(939 \mathrm{Kg})\end{array}$ & 0,78 & 0,66 \\
\hline $\begin{array}{r}\text { Kombinasi } 7 \mathrm{~b} \\
(1051 \mathrm{Kg})\end{array}$ & 0,70 & 0,59 \\
\hline
\end{tabular}

Bila mengacu pada PPBBI 1984 dengan menggunakan faktor keamanan $(\mathrm{SF})=1.5$, kuda-kuda baja ringan dengan atap metal cukup kuat dan cukup kaku untuk memikul beban kombinasi 1a-3a atau dapat dibangun secara lengkap mulai dari penutup atap hingga plafon namun tidak bisa digunakan untuk kondisi darurat evakuasi bencana pengungsi atau beban abu vulkanik. Bila rangka kuda-kuda baja ringan menggunakan penutup genteng tanah liat maka cukup kuat dan cukup kaku memikul beban kombinasi $1 b-3 b$ atau dapat dibangun secara lengkap mulai dari penutup atap hingga plafon namun tidak dapat dipergunakan untuk kondisi darurat bencana. Kuda-kuda baja ringan mencapai batas lendutan ijin pada saat beban kombinasi $4 \mathrm{~b}$ atau dapat dikatakan kudakuda baja ringan cukup kaku untuk menahan beban terpaan angin dan hujan. Kuda-kuda baja ringan akan mengalami lendutan berlebihan ketika dinaiki orang secara beramai-ramai sehingga perlu dilakukan pembatasan beban orang yang naik ke atas atap hingga $80 \mathrm{~kg} / \mathrm{m}^{2}$.

c. Analisis Kegagalan Struktur Rangka Kuda-Kuda 
Dari hasil pengujian full scale pada struktur rangka kuda-kuda baja ringan, kegagalan

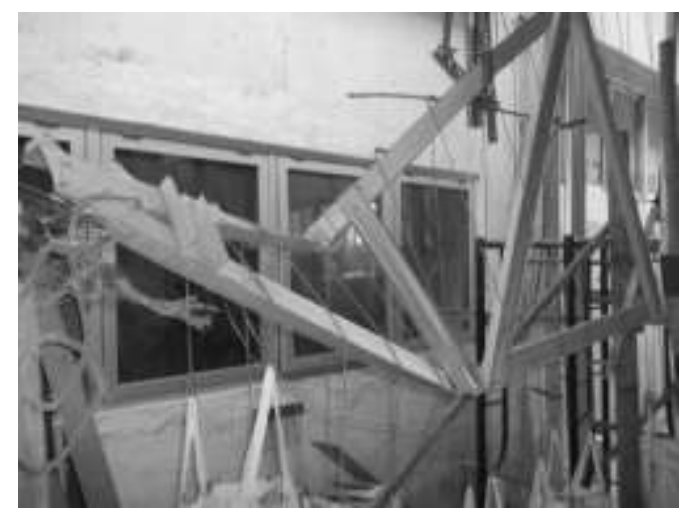

a. Kegagalan tekuk pada batang tekan rangka kuda-kuda baja struktur berupa tekuk/buckling pada batang tekan (Gambar 6).

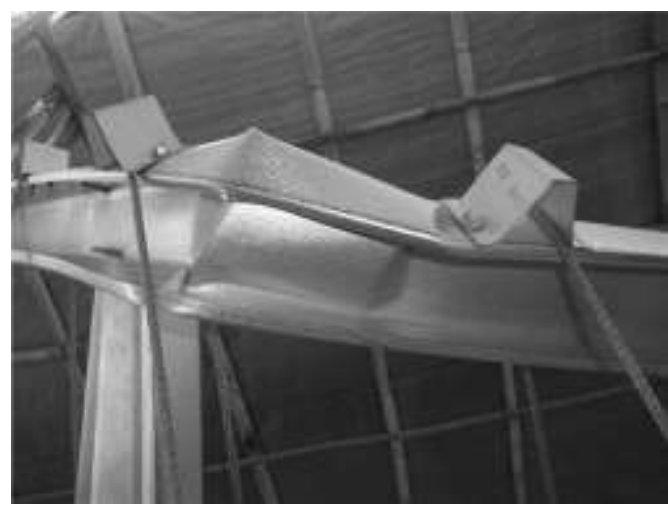

b. Kegagalan tekuk lokal pada batang tekan

Gambar 6. Kegagalan struktur kuda-kuda baja ringan

Mekanisme kegagalan struktur kuda-kuda baja ringan disebabkan oleh :

1. Gaya aksial pada batang tekan hasil pengujian melebihi kapasitas penampang tekan teoritis sehingga batang tekan mengalami tekuk ke arah sumbu lemah.

2. Kegagalan struktur diawali dengan tekuk bagian badan ke arah sumbu Y atau mengalami tekuk lateral ke arah sumbu lemah kemudian diikuti tekuk lokal pada penampang sayap. Kondisi batang tarik baja ringan mengalami kegagalan setelah terjadi tekuk torsi pada batang tekan.

\section{d. Efisiensi Dan Efektifitas Kinerja Struktur Rangka Kuda-Kuda}

Kajian nilai ekonomi rangka kuda-kuda yang meliputi lama pengerjaan dan harga pembuatan kuda-kuda dapat dilihat pada Tabel 4.

Tabel 4. Analisis nilai ekonomi struktur rangka kuda-kuda

\begin{tabular}{|c|c|c|}
\hline No. & Parameter Kinerja & Kuda-Kuda Baja Ringan \\
\hline 1 & Lama pengerjaan kuda-kuda & 2 hari \\
\hline 2 & Total waktu hingga kuda-kuda siap dibebani & 2 hari \\
\hline 3 & Harga & Rp $1,740,000$ \\
\hline 4 & Rasio beban/berat & 34,5 \\
\hline 5 & Rasio harga/beban & $\mathrm{Rp} \quad 870 / \mathrm{kg}$ \\
\hline
\end{tabular}

Ditinjau dari sisi kemudahan dan kecepatan dalam pembuatan kuda-kuda, kuda-kuda baja ringan dinilai cepat karena mengandalkan jenis batang yang sudah terfabrikasi (tidak perlu pengolahan lagi) dan penggunaan sistem baut yang sederhana dalam pemasangannya. Dari sisi harga kuda-kuda baja ringan yang cukup murah memiliki daya tarik bila dibandingkan jenis kuda-kuda lainnya. Struktur rangka kuda-kuda baja ringan dapat dikatakan sangat efektif dalam 
menahan beban bila akan diterapkan masyarakat.

\section{SIMPULAN}

Dari hasil penelitian dan analisis data yang telah dilakukan, maka ditinjai dari sisi manajemen konstruksi, 1set kuda-kuda baja ringan dapat dikerjakan dalam 2 hari dan bisa dikerjakan 2 orang serta memiliki harga yang cukup ekonomis sehingga banyak digemari masyarakat. Ditinjau dari sisi kekuatan, 1 set kuda-kuda baja ringan mampu memikul beban maksimum 734,2 $\mathrm{Kg}$ yang artinya dapat menahan semua kombinasi beban layan (berat sendiri, berat reng, berat penutup atap, beban angin dan air hujan). Rangka kuda-kuda baja ringan dengan penutup genteng tanah liat aman digunakan pada jarak antar kuda-kuda maksimum $0,8 \quad \mathrm{~m}$. Sedangkan bila menggunakan penutup genteng metal, rangka kuda-kuda aman digunakan untuk jarak antar kuda-kuda maksimum 1,2 m. Kuda-kuda baja ringan tidak cocok digunakan untuk kondisi darurat seperti kondisi beban timbunan abu vulkanik gunung berapi, beban pengungsi bencana banjir, atau system pembangunan dengan gotong royong dimana banyak orang naik ke atas struktur namun harus dibatasi 80 $\mathrm{kg} / \mathrm{m}^{2}$.

\section{UCAPAN TERIMA KASIH}

Ucapan terimakasih ditujukan kepada Prof. Ir. Iman Satyarno, M.E, Ph.D dan Dr. Ir. H. Muslikh, M.Sc., M.Phil selaku dosen pembimbing, PT Indocement Tunggal Prakarsa, Tbk atas bantuan dana penelitian serta civitas akademika Jurusan Teknik
Sipil dan Lingkungan, Fakultas Teknik, Universitas Gadjah Mada.

\section{DAFTAR PUSTAKA}

Badan Standarisasi Nasional, 1987, SNI 17.29.1987

(SKBI-1.3.53.1987)

Tatacara Perencanaan

Pembebanan Untuk Rumah Dan Gedung, Jakarta, BSN.

Basukito, R. S, 2010, Stabilitas Kuda-Kuda Baja Ringan Startruss Type $C$ (Studi Kasus : Pengujian KudaKuda Baja Ringan Bentang 6m), Yogyakarta, Universitas Gadjah Mada.

Frick, H. dan Moerdiartianto., 2002, Ilmu

Konstruksi Bangunan Kayu, Yogyakarta, Kanisius.

Rohman, R.K. dan Martana., 2011, Perbandingan Harga Pengunaan Konstruksi Kayu Dan Baja Ringan Sebagai Konstruksi Rangka Atap Pada Bangunan Sederhana, Jurnal Agri-tek volume 12 no. 2 September 2011, Madiun, Universitas Merdeka Madiun.

Utomo, Adityo, dkk, 2016, Pengembangan Rangka Kuda-uda Berbasis Semen, Jakarta, PT Indocement Tunggal Prakarsa

Yap, F., 2001, Konstruksi Kayu. Bandung, Bima Cipta.

Yayasan Lembaga Penyelidikan Masalah Bangunan, 1984, Peraturan Perencanaan Bangunan Baja Indonesia (PPBBI). Bandung, Direktorat Penyelidikan Masalah Bangunan. 